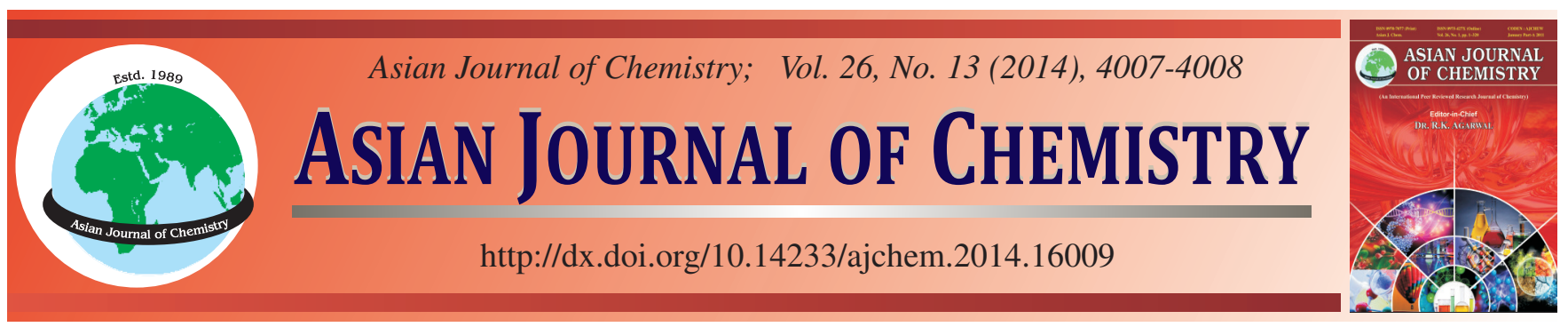

NOTE

\title{
Synthesis and Crystal Structure of Nickel(II) Complex: $\left[\mathrm{Ni}(\mathrm{phen})_{2}\left(\mathrm{~N}_{3}\right)_{2}\right]$
}

\author{
WEN-JIE BI ${ }^{*}$ and HuA-ZE Dong*
}

School of Chemistry and Chemical Engineering, Hefei Normal University, Hefei, P.R. China

*Corresponding authors: E-mail: 501178740@qq.com; dapdong@163.com

\begin{abstract}
A novel nickel(II) complex $\left[\mathrm{Ni}(\text { phen })_{2}\left(\mathrm{~N}_{3}\right)_{2}\right]$ has been synthesized, with the 1,10-phenanthroline (phen) and the nitrine $\left(\mathrm{N}_{3}^{-}\right)$as ligands and characterized by IR spectra and single-crystal X-ray diffraction measurements. The crystal is triclinic, space group P-1 with cell dimensions of $\mathrm{a}=8.2079(7) \AA, \mathrm{b}=11.0042(10) \AA, \mathrm{c}=12.4317(11) \AA, \alpha=82.259(2)^{\circ}, \beta=82.240(2)^{\circ}, \gamma=72.5150(10)^{\circ}, \mathrm{V}=1055.88(16)$ $\AA^{3}, \mathrm{Z}=2, \mathrm{Mr}=503.18, \mathrm{Dc}=1.583 \mathrm{mg} / \mathrm{cm}^{3}, \mu=0.957 \mathrm{~mm}^{-1}, \mathrm{~F}(000)=516, \mathrm{~T}=298(2) \mathrm{K}, \mathrm{R}=0.0372$, wR $=0.0948$ for 5278 reflections with I > 2(I). In the molecular structure unit, nickel(II) cation is coordinated by six donor atoms and has a slightly distorted octahedron configuration.
\end{abstract}

Keywords: Nickel(II) complex, Phenanthroline, Azium, Crystal structure.

1,10-Phenanthroline is a kind of good metal chelating agent and provide two donor atoms. Their complexes have stable chemical property and excellent performance ${ }^{1}$. Nickel is one of necessary trace elements in organisms, nickel(II) complexes have broad application prospects in molecular magnets $^{2,3}$, superoxide dismutase ${ }^{4,5}$, biological activity ${ }^{6,7}$ and catalytic aspects ${ }^{8,9}$. Herein, the synthesis and crystal structure of a mononuclear complex $\left[\mathrm{Ni}(\text { phen })_{2}\left(\mathrm{~N}_{3}\right)_{2}\right]$ are reported.

All reagents were of AR grade and used without further purification. IR spectra were recorded on a Nicolet 870 spectrophotometer. The X-ray structure was determined by Bruker Smart-1000 CCD area-detector diffractometer.

Synthesis: $20 \mathrm{~mL}$ ethanol solution of phen $(10 \mathrm{mmol})$ was respectively added to $20 \mathrm{~mL} \mathrm{H}_{2} \mathrm{O}$ solution of $\mathrm{NiCl}_{2}(5 \mathrm{mmol})$ and $\mathrm{NaN}_{3}(30 \mathrm{mmol})$ under stirring for $4 \mathrm{~h}$. After being filtered, the solution was stand at room temperature for 1 week, crystals were obtained. The product was green cubic-shaped crystals. Yield $46 \%$. IR spectrum $\left(\mathrm{KBr}, \mathrm{cm}^{-1}\right): 3430,2070,1630,1500$, 1429, 852, 719, 636.

Structure determination: A single crystal $(0.44 \mathrm{~mm} \times$ $0.42 \mathrm{~mm} \times 0.40 \mathrm{~mm}$ ) was selected for crystallographic data collection at 298(2) $\mathrm{K}$ and structure determinated with graphite monochromatic $\mathrm{MoK}_{\alpha}$ radiation $(\lambda=0.71073 \AA)$. A total of 5278 reflections were collected in the range of $2.61^{\circ} \leq \theta \leq$ $25.02^{\circ}$, of which 3655 reflections were unique with $\mathrm{R}_{\text {int }}=$ 0.0230 . Lp effects and empirical absorption were applied in data corrections. The structure was solved by direct methods and expanded using fourier techniques and SHELXS-97 program system was used in the solution and refinement of the structure. The non-hydrogen atoms were refined anisotropically. Hydrogen atoms were added according to theoretical model.

$$
\mathrm{R}_{1}=\Sigma\left(|| \mathrm{F}_{0}|-| \mathrm{F}_{\mathrm{c}} \|\right) / \Sigma\left|\mathrm{F}_{0}\right|=0.0372
$$

and

$$
\mathrm{wR}_{2}=\left\{\Sigma\left[\mathrm{w}\left(\mathrm{F}_{0}^{2}-\mathrm{F}_{\mathrm{C}}^{2}\right)^{2}\right] / \Sigma \mathrm{w}\left(\mathrm{F}_{0}^{2}\right)^{2}\right\}^{1 / 2}=0.0948
$$

where $\mathrm{w}=1 /\left[\mathrm{s}^{2}\left(\mathrm{~F}_{0}^{2}\right)+(0.0588 \mathrm{P})^{2}+0.3204 \mathrm{P}\right], \mathrm{P}=\left(\mathrm{F}_{0}{ }^{2}+\right.$ $\left.2 \mathrm{~F}_{0}^{2}\right) / 3$. The maximum and minimum peaks on the final difference fourier map are corresponding to 0.7008 and $0.6782 \mathrm{e} / \AA^{3}$ (CCDC No. 937456), respectively.

The atomic coordinates and thermal parameters are listed in Table-1 and the selected bond lengths and bond angles in Table-2, respectively. Fig. 1 shows diagram of the molecular structure of the complex $\left[\mathrm{Ni}(\text { phen })_{2}\left(\mathrm{~N}_{3}\right)_{2}\right]$. Fig. 2 shows the packing diagram of the complex in the unit cell. As shown in the Fig. 1, the center nickel(II) cation is six-coordinated with four nitrogen atoms of the two 1,10-phenanthroline and two nitrogen atoms of the two $\mathrm{N}_{3}$-anions. $\mathrm{Ni}$ (II) is in a slightly distorted octahedral geometry environment.

\section{ACKNOWLEDGEMENTS}

This work is financially supported by the National Natural Science Foundation of China (No. 21101053) and Key Discipline Foundation of Hefei Normal University. 
TABLE-2

SELECTED BOND LENGTHS $(\AA)$ AND BOND ANGLES $\left({ }^{\circ}\right)$

\begin{tabular}{llllll}
\hline \multicolumn{1}{c}{ Bond } & Length & \multicolumn{1}{c}{ Angle } & \multicolumn{1}{c}{$\left(^{\circ}\right)$} & \multicolumn{1}{c}{ Angle } & $\left(^{\circ}\right)$ \\
\hline $\mathrm{NI}(1)-\mathrm{N}(8)$ & $2.073(2)$ & $\mathrm{N}(4)-\mathrm{Ni}(1)-\mathrm{N}(2)$ & $92.21(8)$ & $\mathrm{N}(8)-\mathrm{Ni}(1)-\mathrm{N}(4)$ & $94.36(9)$ \\
$\mathrm{Ni}(1)-\mathrm{N}(5)$ & $2.095(2)$ & $\mathrm{N}(4)-\mathrm{Ni}(1)-\mathrm{N}(3)$ & $79.03(8)$ & $\mathrm{N}(1)-\mathrm{Ni}(1)-\mathrm{N}(3)$ & $93.04(8)$ \\
$\mathrm{Ni}(1)-\mathrm{N}(3)$ & $2.117(2)$ & $\mathrm{N}(5)-\mathrm{Ni}(1)-\mathrm{N}(3)$ & $88.89(9)$ & $\mathrm{C}(1)-\mathrm{N}(1)-\mathrm{Ni}(1)$ & $128.29(18)$ \\
$\mathrm{N}(2)-\mathrm{C}(10)$ & $1.322(3)$ & $\mathrm{N}(7)-\mathrm{N}(6)-\mathrm{N}(5)$ & $177.3(3)$ & $\mathrm{N}(6)-\mathrm{N}(5)-\mathrm{Ni}(1)$ & $126.04(19)$ \\
$\mathrm{N}(4)-\mathrm{C}(22)$ & $1.328(3)$ & $\mathrm{C}(13)-\mathrm{N}(3)-\mathrm{Ni}(1)$ & $129.24(19)$ & $\mathrm{N}(2)-\mathrm{C}(6)-\mathrm{C}(5)$ & $117.1(2)$ \\
$\mathrm{N}(6)-\mathrm{N}(7)$ & $1.166(3)$ & $\mathrm{C}(1)-\mathrm{N}(1)-\mathrm{Ni}(1)$ & $128.29(18)$ & $\mathrm{N}(3)-\mathrm{C}(13)-\mathrm{C}(14)$ & $122.9(3)$ \\
\hline
\end{tabular}

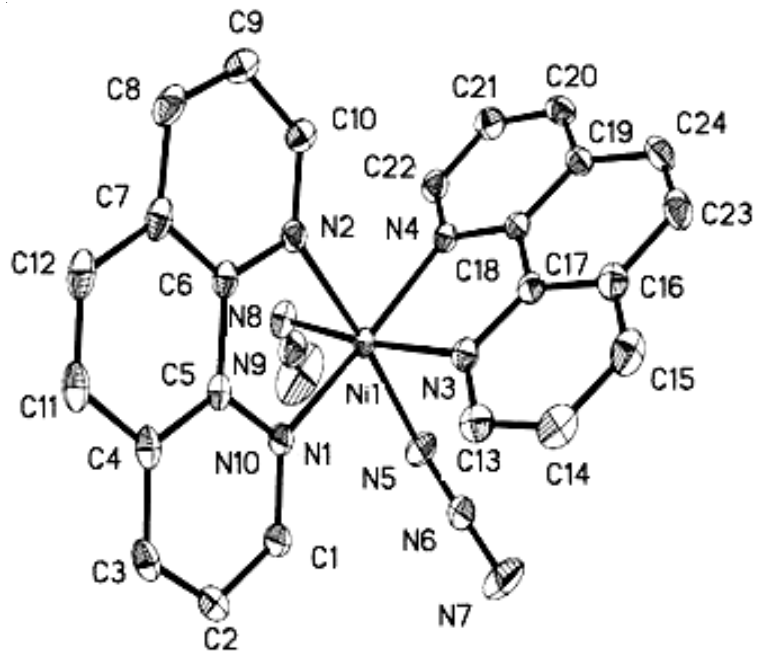

Fig. 1. Molecular structure of the complex $\left[\mathrm{Ni}(\mathrm{phen})_{2}\left(\mathrm{~N}_{3}\right)_{2}\right]$

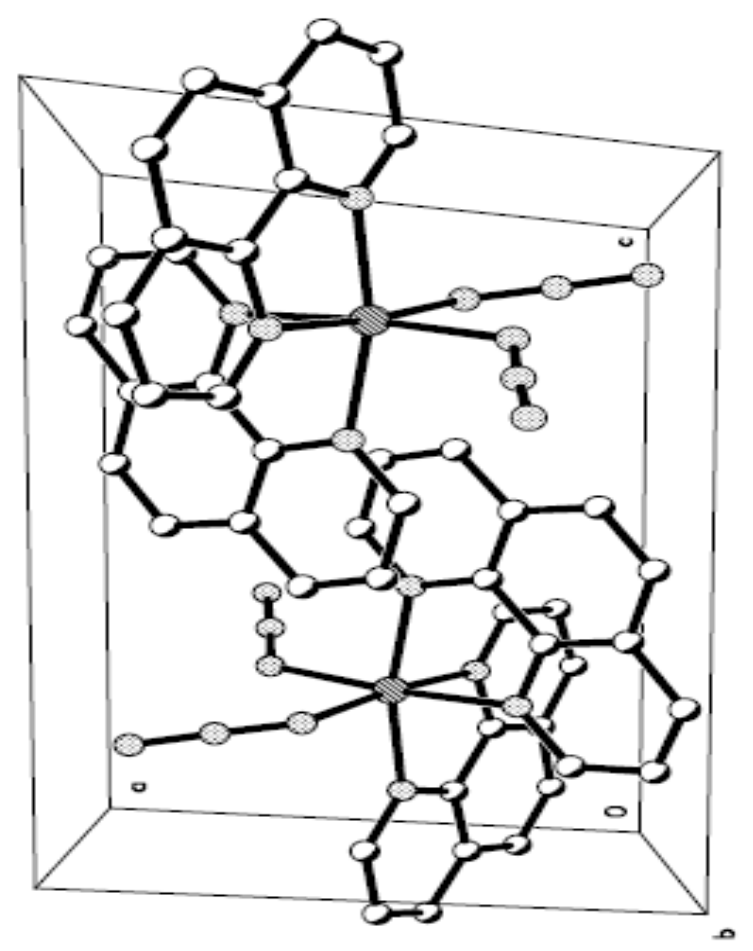

Fig. 2. Molecular packing arrangement in the unit cell
TABLE-1

NON-HYDROGEN ATOMIC COORDINATES $\left(\times 10^{4}\right)$ AND THERMAL PARAMETERS $\left(\times 10^{3} \AA^{2}\right)$

\begin{tabular}{ccccc}
\hline Atom & $\mathrm{X}$ & $\mathrm{Y}$ & $\mathrm{Z}$ & $\mathrm{U}(\mathrm{eq})$ \\
\hline $\mathrm{NI}(1)$ & $5172(1)$ & $7118(1)$ & $7652(1)$ & $27(1)$ \\
$\mathrm{N}(2)$ & $7337(3)$ & $5481(2)$ & $7685(2)$ & $30(1)$ \\
$\mathrm{N}(3)$ & $6727(3)$ & $8376(2)$ & $7339(2)$ & $29(1)$ \\
$\mathrm{N}(4)$ & $5378(3)$ & $7446(2)$ & $9234(2)$ & $30(1)$ \\
$\mathrm{N}(5)$ & $3008(3)$ & $8702(2)$ & $7470(2)$ & $41(1)$ \\
$\mathrm{N}(6)$ & $2966(3)$ & $9661(2)$ & $6912(2)$ & $36(1)$ \\
$\mathrm{N}(7)$ & $2863(4)$ & $10634(3)$ & $6382(3)$ & $67(1)$ \\
$\mathrm{N}(8)$ & $3653(3)$ & $5901(2)$ & $8147(2)$ & $42(1)$ \\
\hline
\end{tabular}

\section{REFERENCES}

1. C.M. Liu, Y.L. Hou, J. Zhang and S. Gao, Inorg. Chem., 41, 140 (2002).

2. L.K. Thompson, Coord. Chem. Rev., 233-234, 193 (2002).

3. Z.G. Gu, W. Liu, Q.F. Yang, X.-H. Zhou, J.-L. Zuo and X.-Z. You, Inorg. Chem., 46, 3236 (2007).

4. H. Miyasaka, S. Furukawa, S. Yanagida, K.-i. Sugiura and M. Yamashita, Inorg. Chim. Acta, 357, 1619 (2003).

5. X.C. Yao, L. Zhu, Y. Chen, J. Tian and Y. Wang, Food Chem., 139, 59 (2013).

6. K.C. Skyrianou, V. Psycharis, C.P. Raptopoulou, D.P. Kessissoglou and G. Psomas, J. Inorg. Biochem., 105, 63 (2011).

7. M.C. Rodrìguez-Argüelles, M.B. Ferrari, F. Bisceglie, C. Pelizzi, G. Pelosi, S. Pinelli and M. Sassi, J. Inorg. Biochem., 98, 313 (2004).

8. H.Z. Dong, W.B. Tao, J. Bi, V. Milway, Z. Xu, S. Zhang, X. Meng, W. Bi, J. Li and M. Li, Nanoscale Res. Lett., 6, 484 (2011).

9. H.S. Abbo, S.J.J. Titinchi, R. Prasad and S. Chand, J. Mol. Catal. A, 225, 225 (2005). 